\title{
Evaluation of Methodology PBL Done by Students
}

\author{
B. AMANTE, A. LACAYO, M. PIQUÉ, S. OLIVER, P.PONSA, R. VILANOVA \\ Technical University of Catalonia (UPC) and Autonomous University of Barcelona (UAB) \\ Engineering Projects Department. ETSEIAT (Industrial Engineering and Aeronautics School). \\ Carrer Colom, 11, 08222 Terrassa (BCN) Spain.
}

beatriz.amante@upc.edu, alex.lacayo@estudiant.upc.edu,marc.pique-miserachs@estudiant.upc.edu, sonia.oliver@uab.cat, pere.ponsa@upc.edu; ramon.vilanova@uab.cat

\section{ABSTRACT}

This article presents the application of PBL (Project Based Learning) methodology in a subject called Projects within the degree of Industrial Organization (ETSEIATUPC) and includes a detailed feedback from students in terms of their "experiences and feelings" about such implementation. It is, therefore, a real project carried out by students in which they themselves assume responsibilities and, hence, perform an active role in their own learning process always following the guidelines set by the professor, who designs specific activities or recreates scenarios accordingly.
Thereby, in the present article we explain how a group of students assess PBL methodology in their tuition and practice and, especially, when carrying out and finishing a set project. Our contribution, then, goes a step further than usual as it deals with more than just filling up questionnaires and gathering opinions but it incorporates students' views on the methodological tools used both in the theoretical and practical sessions which offers us, professors, a very useful inside information of students' perceptions an views while using PBL for their Engineering project.

KEYWORDS Active methodologies, Problem-Based Learning (PBL), Project-Based Learning (PBL), teaching quality and student's view. 


\section{INTRODUCTION}

Following nowadays trend towards European convergence, with free circulation of citizens and recognition of University degrees within the E.C. (European Community) members, Engineering Schools are aiming at designing new curricula $[1,2,3]$, to fit such challenge. A challenge that will be articulated pursuing the following goals:

- To develop a greater research capacity and to improve teaching quality

- To motivate students by posing them real problems or challenges

- To prepare students for their professional careers in a multidisciplinary context and to guarantee their formative contents learning.

- To enhance cross-curricular competencies, such as working in a team, dealing with interpersonal interaction and expressing oneself both written and orally, among others.

So as to meet the challenge, new learning methodologies are approached as it is the case of PBL (Problem/Project- Based Learning) [3,4,5,6,7]. These learning methodologies are based on group work and allow students play a role and assume responsibilities as a part of their active role in their learning process. This is possible thanks to the guidelines, activities and scenarios that the professor creates on purpose. In addition, such methodology makes it possible to perceive individual's characteristics in terms of ways to approach a matter and deal with it. This new methodological tool, therefore, allows professors to follow student's progress individually and guarantees a formative assessment which was not used before.

Since the development of PBL model by the University of McMaster in Canada in the late 60's, many alternative approaches of the process have been presented [8]. The present article shows how PBL was implemented in a subject called Projects (within the Industrial Organization degree) in the Technical University of Catalonia at ETSEIAT Technical School. By carefully explaining students" "experiences and feelings" about this methodology we will be able to observe how they analyze the methodological tools provided by the professor during both theory and practice sessions in the subject, then, being able to gather precious data on students' assessment in terms of use and suitability.

Projects is a core content subject of 6 credits in the ECTS (European Credit Transfer System) which is taught in the last year of Engineering studies, just before students start their professional career. And this is the main reason why we make them "face" real Engineering problems in this subject. It is precisely this way that students are able to solve a real problem by applying all the knowledge acquired throughout the degree and by carrying out a project in groups and supervised by a tutor (professor).

As to the main objectives of Projects subject, they can be summarized as follows:

- To understand the basic concepts under the meaning of "Projecting"

- To use both teamwork and individual work methodologies to carry out projects and solve problems when managing them

- To enhance students' creativity

- To number and identify the possible problems to be solved when carrying out an Industrial project

- To analyze and assess the alternatives provided to solve the matter/s

- To analyze the organization, timing and economics' management of a project

Hence, the competencies developed in this subject are: "teamwork, oral and written skills, initiative, leadership, planning abilities, efficient search of information and, more recently, the application of audiovisual tools or ICTs (Information and Communication Technologies). Every academic year three of these competencies are enhanced and measured although many more may be developed.

\section{METHODOLOGY}

As we have already mentioned, Projects subjecttaught within the degree of Industrial Organization (IO)- has been gradually changed in terms of methodology and during the last few years it has incorporated PBL[9,10,11,12]. Not to mention, this is posible because of the existing links between subjects in the degree. Projects, then, could be defined as the integration and application of the technological and specific knowledge acquired throughout the degree. We may illustrate this point with the case of a real problem that has arisen in our University recently and it has to do with the need of a robotized parking system or other likely issues, such as the application of new technologies in public areas, the installation of solar panels in the Town Hall or the adaptation of underground lines to facilitate handicapped people's mobility.

This subject consists of 5 presential hours for the student, which are divided into 2 hours of theory and $3 \mathrm{~h}$ of practice weekly. The tuition is used to provide students with generic and formal contents (i.e. documents of a project) as well as specific contents, for example: work planning, time management, alternative solutions search, quantitative and qualitative decision taking methodologies and budgeting or making quotations according to the nature of the study or project to be carried out. Moreover, at the end of each unit, 
students provide feedback on their learning and topic acquisition by filling up several self-assessment questionnaires using Atenea, a virtual campus for teaching support in our University.

It is in the practical part of the subject when students enhance competencies through the development of the project. Besides from this task, another activity related to the general syllabus is carried out on a weekly basis so that students can practice and enhance the varied skills required to work in a group.

The activities start with a theoretical case posed by the professor that has to be solved by students. They are then required to hand in a short written report and have to carry out an oral presentation accordingly. Some of the topics to be dealt with there are, obviously, leadership, planning, conflicts' management or motivation.

Turning now into the practical side of the subject, students are faced with a project/problem right at the beginning of the sessions and have 4 months to solve it. With this goal in mind, students are divided into groups to work as if they were employees working for an Engineering company. Usually, and always according to the number of students enrolled in the subject, the size of the groups range from 6 to 10 members.

Within each group there are two key roles to be played: the Co-ordinator and the Secretary. Both of them are in charge of distributing tasks and setting deadlines of teamwork weekly. In addition, the Co-ordinator will elaborate a report that will be handed to and commented with the Tutor and in which he/she will indicate the individual work of each of the group members.

Each meeting of the group will be registered in a Minute book that will include all the topics covered and the remaining tasks to be performed before the following session. In Table 1, we have compiled all the documents given to students at the beginning of the subject and to be used throughout the 4 months it lasts.

In this period of time students must hand in two tasks related with their Project. The first one consisting in recording a video in which they themselves will explain their Project in progress together with a short written report. This presentation will be evaluated both by professors and classmates from other groups. This way a close follow-up of the projects in progress can be done. Not to mention, the possibility of getting very useful feedback as ideas for improvement may arise

The second task will be carried out at the end of the subject and will consist in presenting the definite version of the Project in written format(summary, budget/quotation, appendices) and any other document required to develop a project in the real world. Besides, students will be asked to do an oral presentation in front of a jury formed by professors from the Department itself (who may not be teaching this subject) and their classmates. This jury tries to imitate the presentations that students have to do at the end of their studies (final project) and will assess the content of the work presented as well as its oral presentation and the poster created as a summary of the project. Obviously, the professor or tutor of the practical part of the subject will be part of such jury and will provide a global view of students' work performed throughout the whole term.

As to the oral presentation assessment criteria, we have summarized it in Table 2. Students themselves know all the quality indicators beforehand $[13,14,15,16]$.

Table 1. Selection of documents provided to students to guide a correct performance of the practical part of the subject.

\begin{tabular}{|c|c|}
\hline Tool & $\begin{array}{l}\text { Purpose } \\
\text { of the document }\end{array}$ \\
\hline Meeting statements & $\begin{array}{l}\text { This written statement } \\
\text { helps seeing the evolution of } \\
\text { the work in progress and } \\
\text { the members of the group } \\
\text { who work less. It also } \\
\text { facilitates the task of } \\
\text { writing a weekly report by } \\
\text { the group's coordinator. }\end{array}$ \\
\hline Weekly reports & $\begin{array}{l}\text { This is the document that } \\
\text { allows to observe the } \\
\text { leadership skills of both the } \\
\text { coordinator and the } \\
\text { planner in each group. } \\
\text { Moreover, it makes the } \\
\text { assessment of the group } \\
\text { work in progress much } \\
\text { easier. }\end{array}$ \\
\hline Assessment Questionnaires & $\begin{array}{l}\text { They are used to evaluate } \\
\text { the work each member has } \\
\text { put into the project as well } \\
\text { as the self-assessment of } \\
\text { individuals in the group. }\end{array}$ \\
\hline Delivery formats & $\begin{array}{l}\text { These are the documents } \\
\text { that explain the format of } \\
\text { the different deliveries } \\
\text { (project, poster, etc.) }\end{array}$ \\
\hline $\begin{array}{l}\text { Evaluation criteria and oral } \\
\text { assessment grid }\end{array}$ & $\begin{array}{l}\text { These documents are very } \\
\text { useful to students in terms } \\
\text { of knowing where to } \\
\text { emphasize or correct their } \\
\text { oral presentations } \\
\text { beforehand. }\end{array}$ \\
\hline
\end{tabular}

All groups, as we have just mentioned, have to design a poster to back up their oral presentation in this second and final part of the Project development. The poster, therefore, has to highlight the project's main ideas, students' performance and significant data without 
overlooking its visual design and its potential as a marketing tool to sell the project/ideas.

Table 2. Selection of documents provided to students to guide a correct performance of the practical part of the subject.

\begin{tabular}{|c|c|}
\hline $\begin{array}{c}\text { Evaluation } \\
\text { criteria(parameters) }\end{array}$ & Descriptors \\
\hline Clarity of ideas & $\begin{array}{l}\text { The contents of the } \\
\text { presentation are fully } \\
\text { understood. }\end{array}$ \\
\hline Self-confidence & $\begin{array}{l}\text { The student seems nervous, } \\
\text { shakes and/or seems to have } \\
\text { problems of delivery } \\
\text { speed/tone/voice, etc. }\end{array}$ \\
\hline $\begin{array}{l}\text { Oral explanation not } \\
\text { reading }\end{array}$ & $\begin{array}{l}\text { The student adds information } \\
\text { to the one provided in the } \\
\text { slides }\end{array}$ \\
\hline $\begin{array}{l}\text { Coherence and } \\
\text { cohesion of the slides } \\
\text { presented }\end{array}$ & $\begin{array}{l}\text { The student uses linkers and } \\
\text { suitable connectors to } \\
\text { present and explain the } \\
\text { different slides and defines } \\
\text { the different stages in the } \\
\text { information process. }\end{array}$ \\
\hline $\begin{array}{l}\text { Length of the } \\
\text { presentation }\end{array}$ & $\begin{array}{l}\text { The time used in the oral } \\
\text { presentation is suitable and } \\
\text { follows the initial timing. } \\
\text { Proper speed of delivery. }\end{array}$ \\
\hline Position/Attitude & $\begin{array}{l}\text { The student shows } \\
\text { enthusiasm /rhythm and } \\
\text { signals the required objects } \\
\text { in the slides. }\end{array}$ \\
\hline $\begin{array}{l}\text { Argumentative/reason } \\
\text { ing skills }\end{array}$ & $\begin{array}{l}\text { The student is able to present } \\
\text { arguments in a persuasive } \\
\text { way and support his/her } \\
\text { reasoning. }\end{array}$ \\
\hline $\begin{array}{l}\text { Coherence in } \\
\text { answering questions }\end{array}$ & $\begin{array}{l}\text { The student is able to give a } \\
\text { quick an appropriate answer } \\
\text { to the questions both the } \\
\text { teacher and the classmates } \\
\text { may make. }\end{array}$ \\
\hline
\end{tabular}

So as to hand in the set tasks throughout the term, to enhance communication between professors and students and to spread or post didactic/educational material two different virtual

Platforms/environments are used to aid the teaching and learning processes. The first one, as we have previously mentioned, is called Atenea- a virtual campus used by the whole University (UPC) and working through Moodle and the second one is called $B S C W$ (Basic Support for Cooperative work), a very useful network used by the Projects Engineering Department staff, mainly used to share information with a group of students in particular.

Table 3. Example of a scoring rubric

\begin{tabular}{|c|c|c|c|c|}
\hline \multicolumn{2}{|c|}{\begin{tabular}{|c|}
$\begin{array}{c}\text { Application of the concepts } \\
\text { specific to the project area } \\
\text { (ICC3) }\end{array}$ \\
\end{tabular}} & \multicolumn{3}{|c|}{ Course } \\
\hline SCORE & DESCRIPTION & Group 1 & Group 2 & Group... \\
\hline 0 & $\begin{array}{l}\text { The concepts under } \\
\text { project area have } \\
\text { not been considered } \\
\text { or have been used } \\
\text { in a totally incorrect } \\
\text { way }\end{array}$ & & & \\
\hline 1 & $\begin{array}{l}\text { The concepts under } \\
\text { project area are } \\
\text { taken into account } \\
\text { but in many cases } \\
\text { using them wrongly }\end{array}$ & & & \\
\hline 3 & $\begin{array}{l}\text { Particular concepts } \\
\text { of area projects are } \\
\text { included in the } \\
\text { project and have } \\
\text { been used mostly } \\
\text { correctly }\end{array}$ & & & \\
\hline 5 & $\begin{array}{l}\text { The use of concepts } \\
\text { specific to the } \\
\text { project area has } \\
\text { been excellent and } \\
\text { could be regarded } \\
\text { as exemplary }\end{array}$ & & & \\
\hline & Rating ICC3 $=$ & & & \\
\hline
\end{tabular}

Once defined our working methodology, we will move now into the presentation of our results. The following data has been compiled after comparing the different methodological tools used in the Projects subject and obtaining students' global view on them.

\section{RESULTS}

In the first place, we will analyze the methodological tools used by professors and students throughout the development of the subject. Students' view on PBL implementation will be key to understand their interest on this methodological challenge, its possible usefulness and the degree of improvement in the teaching of Projects after its application 


\subsection{Scoring Rubrics}

Both Tutors, professors who are members of the jury and classmates end up using a series of tables where the assessment criteria are carefully specified and shaped in a scale punctuation format (either numerical or descriptive). This evaluation tool (the Table) is used to assess the many aspects to be considered in each task performed in the subject. In these Tables we can find several indicators related to format, content, oral skills, design, etc.

Table 3 is a clear example of the part of the scoring rubric which deals with the application of the concepts specifically related to the Projects area learnt in its theoretical part. In this case the assessment is numerical.

We have to mention here that the use of this tool is perceived very positively by students as they know beforehand the specific criteria that will be used to assess their performance. Students think that by having this information before they have to actually do any assignment helps them focus on the particular duty, hence, improving the quality of their job and presentation.

\subsection{Self-assessment questionnaires on theory acquisition}

As previously mentioned, students were asked to fill in a series of questionnaires once they had finished studying each and every theoretical topic of the subject

The main use of this practice is arising students' awareness of their level of acquisition in terms of assimilating concepts and mastering the knowledge conveyed in each theory session. This way the learner can strengthen the weakest points before the final evaluation as through the use of virtual platform mistakes are corrected and commented right away and, most of all, this teaching support is adapted to the different rhythms of student's learning. Students, therefore, can use this virtual campus to fill in each questionnaire with sufficient time ( 2 weeks is the time allowed per questionnaire).

On the other hand, professors can use the results obtained in these questionnaires to get a very precise idea of the degree of assimilation students have on the content explained in the sessions and realize the theory that has not been understood properly.

\subsection{Learning and discusión forum}

Forums for discussion and debate are periodically opened in Atenea's virtual platform. The main idea here is to encourage discussion on the topics related to specific areas of the subject's syllabus, especially those with a high level of complexity but this activity takes place outside the regular classes. Thereby, students are asked to give their opinions once they have contrasted information and can support their ideas with data they have gathered while searching for information. This activity enhances both selflearning and teamwork as the discussion becomes richer when all the ideas are shared in a common digital space.

However, students do not seem to participate very actively in these discussion exercises as they consider very time consuming the task of searching information and providing feedback. Moreover, the learning of specific content might be difficult in terms of lacking a specific spot for guiding student's writing, sharing classmates' compositions, etc. Therefore, topics should be picked up very carefully so as to be accepted and followed by students' community.

This particular point should be approached differently to make it useful and essential for our students. Probably, it should be better guided so that students knew what they are asked in every precise moment.

\subsection{Real cases}

In the practical sessions planning we have also included short weekly presentations on solving problem cases theoretically. This activity consists, then, in short PBL tasks focused on a particular topic, as is the case of Leadership, time Management, etc.

Students, in general, think that this is a very good method to solve problems they may face when starting their professional careers. Besides, this technique provides them with a wide theoretical Framework and very useful tools. Day by day, students seem to improve in their oral presentation skills, their fluency, their interaction with the audience and the group management, among other advantages.

\subsection{ICTs Platforms in use: Atenea and BSCW}

These virtual platforms are highly used by students as they perceive the many good points they have. For example, facilitating teaching material exchange, making delivery of projects/tasks more flexible and saving paper when not printing documents. Nevertheless, when having more than one option (as it is the case), one must prioritize the use of each teaching aid so as not to duplicate material, lead to confusion or lose any data.

From the experience above described we can infer that there is no need to use two virtual platforms as students will do just fine with one.

Therefore, and from students' feedback we strongly recommend using Atenea as this platform aids both the teaching and learning processes and has a higher performance in terms of visual display and greater functionality. Not to mention, this is the digital support the student already knows from studying all the other subjects 
and there is no need, then, to provide them with any formative session on new programs.

\subsection{Poster Presentation}

This is the tool through which students will apply and improve their skills on synthesizing information by using a totally graphic support as the poster is. Most likely, students will not be familiar with this method of delivering a speech and presenting a Project before this stage of PBL implementation in the classroom and the subject.

It is, therefore, an idea that appeals most students as it is something new and a way of expressing ideas very clearly, quickly and in such a manner that may reach most targeted audiences. A format, as well, that will allow them to present any event, project, product or idea as seen in Figure 1 below.

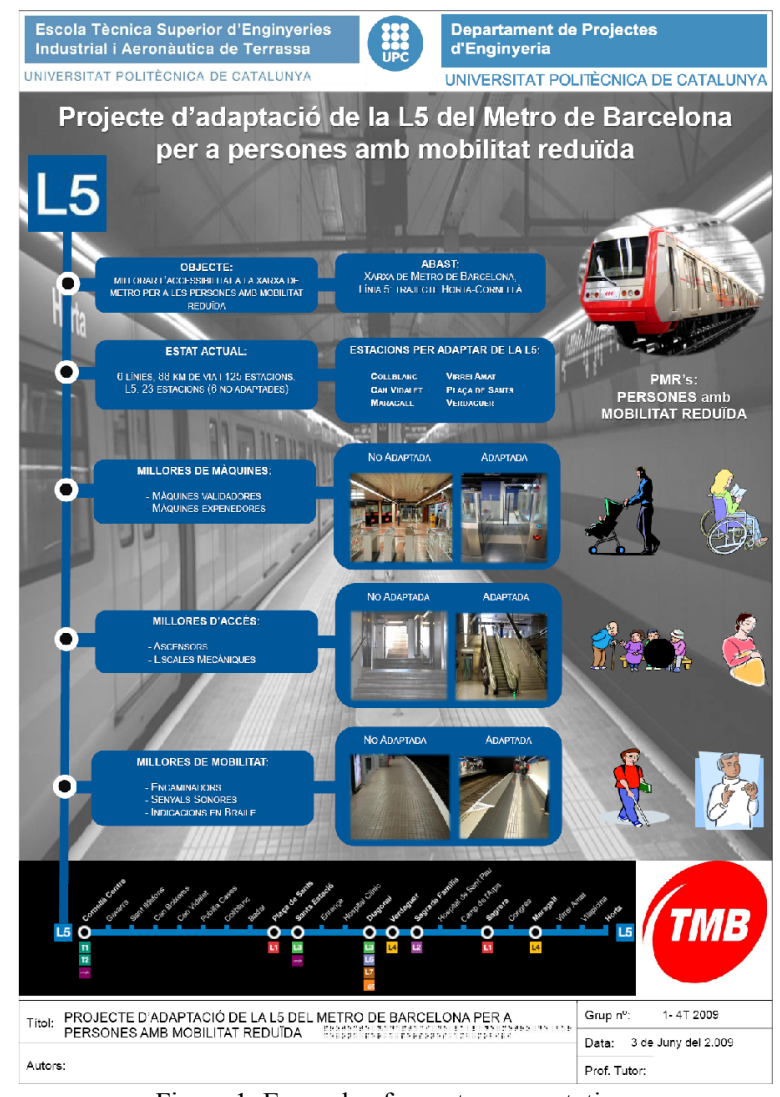

Figure 1. Example of a poster presentation

\subsection{Surveys}

During the course and mostly at its end students are asked to fill in questionnaires, which will provide professors with very useful inside information on their students' perceptions in terms of teacher's quality, amount of content learnt, materials being used, etc. But we will mainly focus on the surveys especially designed for getting student's selfassessment, which are really useful both for them and their teachers.
In these self-assessment questionnaires, the student objectively determines the punctuation of each exercise or project basing his/her mark on a precise rubric given by the professor (including assessment criteria and descriptors). This way student get familiar with the habit of analysing their own work and highlighting their weakest and strongest points in it. It is, hence, an excellent activity for selfcriticism.

In addition, other feedback obtained from peerassessment will contribute in considering other points of view different from the tutor's. All in all, is a very productive activity as assessing classmates' exercises makes each student face the task of evaluating other's work and giving reasons for given mark, pointing out not only mistakes but also good points in it. Therefore, this kind of activities should not be underestimated as if the criteria is well-defined, students consider them useful and relevant.

In Figure 2 below we have included a graphic example of the results obtained in the students' self-assessment questionnaire on Projects subject. In this survey, students indicated their degree of implication in the subject, their interaction within the group, their motivation, initiative and contribution of ideas, among others.

\subsection{Video}

Just like in the case of the poster format, using a video as a tool for synthesizing information and presenting the content of a project is very well received by most students, who see in it a very attractive methodology to show their progress and find new ways to express and promote their ideas. A methodological tool that suits nowadays society requirements perfectly as people are more and more used to digital formats and dealing with visual aids.

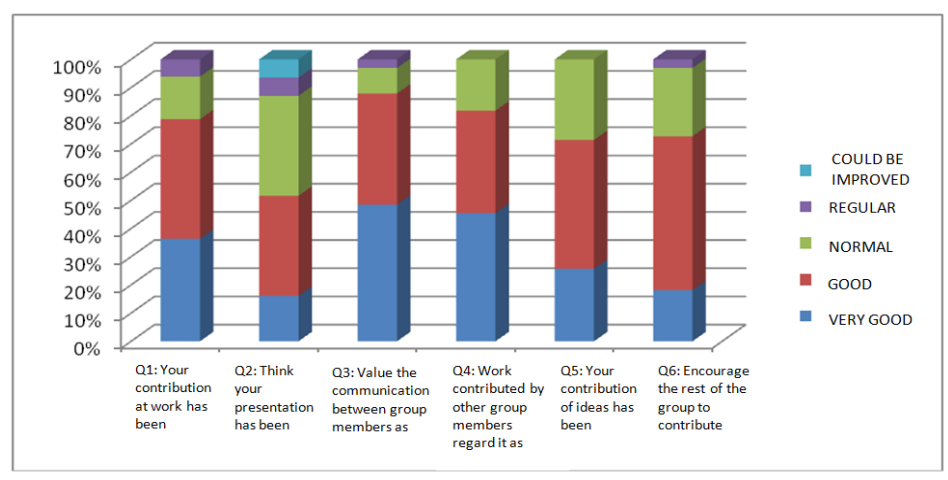

Figure 2. Results of students' self-assessment survey on Projects subject

Moreover, a video shapes one of the best ways to spread knowledge as is the case of the existing platform 
"youtube", which allows for a more flexible learning and can reach thousands of potential users.

One of the main drawbacks, however, is the lack of resources needed to carry out video recordings. But, in the end, we have to bear in mind that we are aiming at producing low-cost teaching videos not a professional footage [17].

It is worth mentioning here that introducing students to video making is something quite new for the teamwork dynamics as they must coordinate resources proficiently (both human and material), challenge their previous ideas and master new programmes, such as video editing software, which very likely they are not familiar with.

In Figure 3 we can see a graph consisting on the results of students' evaluation of the different groups videos, in which they punctuate how original they have been (original, not too original or very original). The questionnaire per se includes descriptors which value the effective transmission of targeted information, the understanding of the whole project, etc.

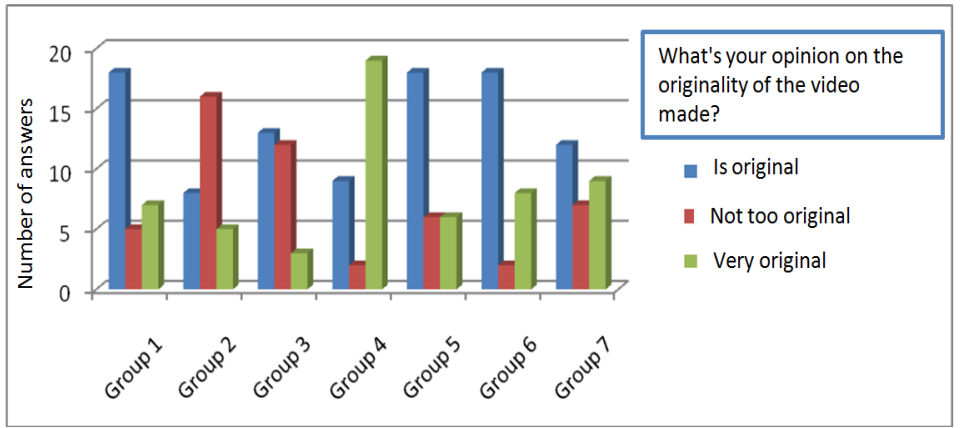

Figure 3. Example of ratings of videos by other groups

\section{Conclusions}

As stated, there is an obvious motivation in higher education towards changes leading to the European convergence of university studies and our Technical Schools in the Polytechnic University of Catalonia (UPC) are no exception. Problem/Project Based Learning (PBL), is already being widely used within the European Higher Education Area (EHEA) framework.

In the present paper, we have aimed at explaining widely and also in detail our students' views and perceptions on the varied tools implemented in the Projects subject following PBL methodology.

On the one hand, throughout the teaching innovation we have realized that some tools, such as the Forum or the excessive use of virtual platforms need to be redefined as its structure should benefit students' learning not making it more difficult.
On the other hand, the use of students' satisfaction questionnaires and self-assessment surveys together with the implementation of new audiovisual tools (i.e, videos and posters) and real cases problem/project solving seem to encourage students' participation and increase motivation. One of the clues here could be that this methodology favours the fact that future engineers are forced to face potential problems in their careers beforehand. Hence, they perceive a closer relationship between their university studies and their real professions while they are managing and leading teamwork.

Moreover, students really appreciate knowing the exact descriptors that are going to be used as a criteria to assess their tasks as they may focus on improvement all the way through.

Finally, PBL methodology allows the practical application of acquired knowledge in other subjects, which being more classical conceptualized, prevent students from practising. Last but not least, essential competencies required for the real professional world of an engineer are enhanced through these new learning methodological approaches.

\section{References}

[1] S. Sarin, "Quality assurance in engineering education: a comparison of EC-2000 and ISO-9000", International Jornal of Engineering Education, 89 (4), (2000), pp. 495-501.

[2] J. Fredericks Volkwein, Lisa R. Lattuca and P. T. Tenerzini, L. C. Strauss and S. Javzan, "Ingineering change: a study if the impact of EC2000" International Journal of Engineering Education, 20(3), "004, pp318-328.

[3] P. Ponsa, B. Amante, J.A. Roman, S. Olivier, M. Díaz, J. Vives. "Higher Education Challenges: Introduction of Active Methodologies in Engineering Curricula" International Journal of Engineering Education, Vol 25, № 4pp 799-813, 2009.

[4] F. Ramos and E. Espinosa, A self-learning environment base don the PBL approach:an application to the learning process in the field of robotics and manufacturing systems, International Journal of Engineering Education. 19(5), pp754-758, 2003

[5] B.J. Duch, S.E. Groh,; D.E. Allen, «The power of problem-based learning». Stylus publishing, 2001

[6] J. Barà, “Aprendizaje basado en problemas / proyectos: ¿qué, por qué, cómo?", institut de ciències de l'educació, julio 2003.

[7] F.J. Sanchez, "Cooperative learning in the digital electronics course at the epsc-upc". International conference on engineering education, icee03, valencia, spain (2003).

[8] G. Jiménez, A. Jiménez, R. Senhadji, J.L. Sevillano, A. Linares, M.A. Rodríguez "Aprendizaje por proyectos en la enseñanza de los microcontroladores". 17 CUIEET - Congreso Universitario de Innovación Educativa en las Enseñanzas Técnicas. Valencia, Spain.

[9] Garcia Almiñana, Daniel Amante Garcia, Beatriz "Metodologías de aplicación del AC y del abp en asignaturas técnicas - teoría y laboratorios" cuieet Gijón 27,28 y 29 de septiembre. 2006

[10] García D., Vives J., “Organització de la informació de treball en entorns d'ensenyament virtuals $i$ cooperatius: l'experiència de projectes d'enginyeria" xii congreso universitario de innovación en las enseñanzas técnicas. Barcelona, julio 2004

[11] García, D., Armelin, E., " $P B L+C W=$ ¿una combinación exitosa?" Ix congreso internacional de ingeniería de proyectos. Málaga, junio 2005.

[12] Armelin, E., García, D., "Fórmulas magistrales" jac'05 quintas jornadas sobre aprendizaje cooperativo. Bilbao, junio 2005.

[13] Daniel García Almiñana, Beatriz Amante Garcia "Algunas reflexiones en torno a la enseñanza de proyectos basada en entornos colaborativos". 
$15^{\circ}$ congreso universitario de innovación educativa en las enseñanzas técnicas Valladolid; july 18-20 2007.

[14] B. Amante García y C. Romero García. "Estudio comparativo de la introducción de aprendizaje cooperativo en diferentes titulaciones técnicas." Revista iberoamericana de educación, 10 marzo 2007

[15] Beatriz Amante, Carmen Romero, Juan Piñuela. "Aceptación de la metodología de aprendizaje cooperativo en diferentes ciclos de carreras técnicas". Artículo en revista: "cuadernos de innovación educativa en las enseñanzas técnicas universitarias". Vol:1 pág. 17-26, Gijón. 2007,

[16] Carmen Romero García, Beatriz Amante García "Formación de competencias utilizando la metodología de aprendizaje cooperativo" ;Valladolid jac 2007;

[17] P. Simó, V. Fernández, I. Algaba, N. Salán, M. Enache, M. Albareda, E. R. Bravo, A. Suñé, D. García, B. Amante, M. "Video Stream and teaching channels Quantitative analysis of the use of low-cost educational video on the Web". World Conference on Educational Sciences, 4-8, 2010 Turkey. 

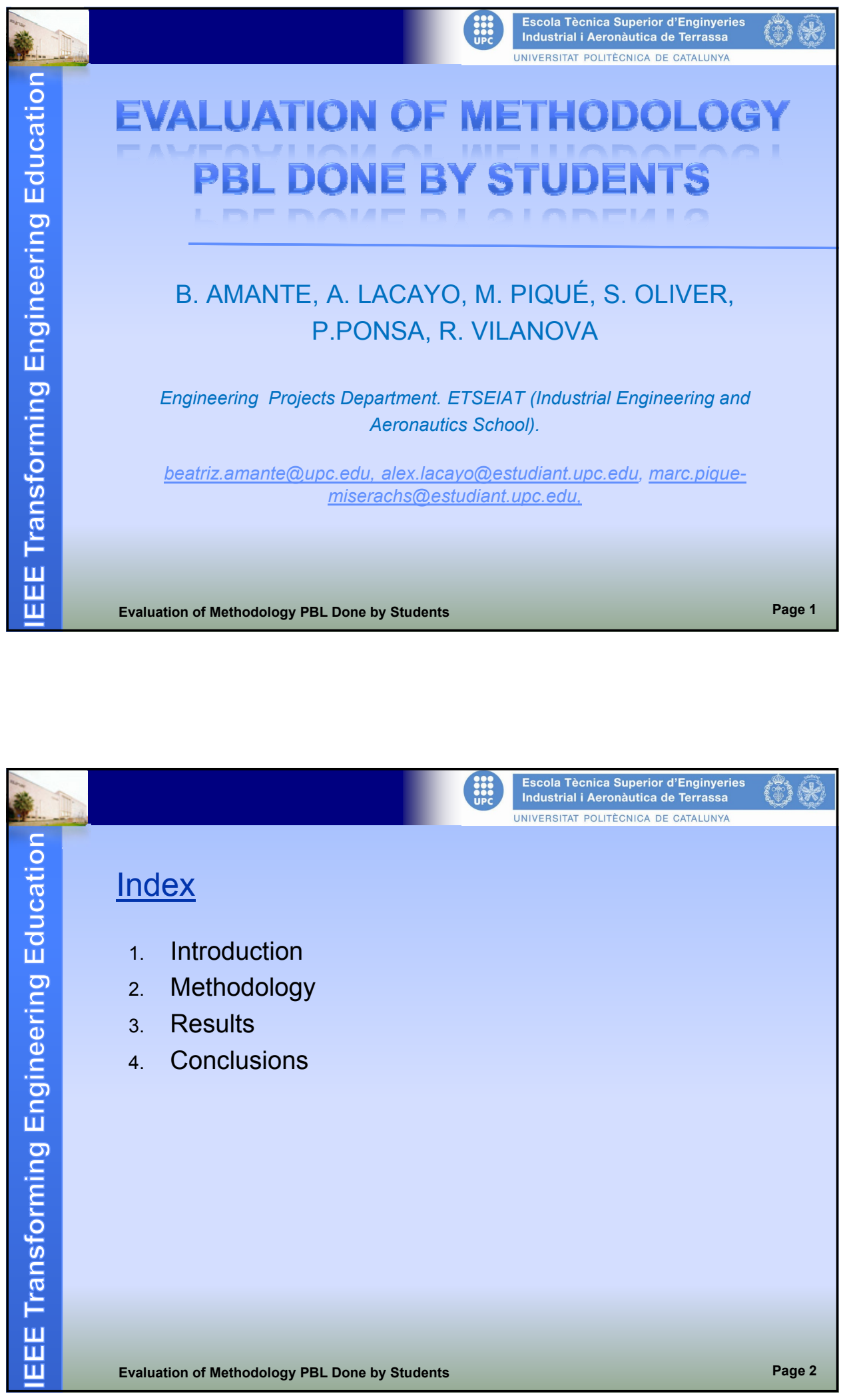

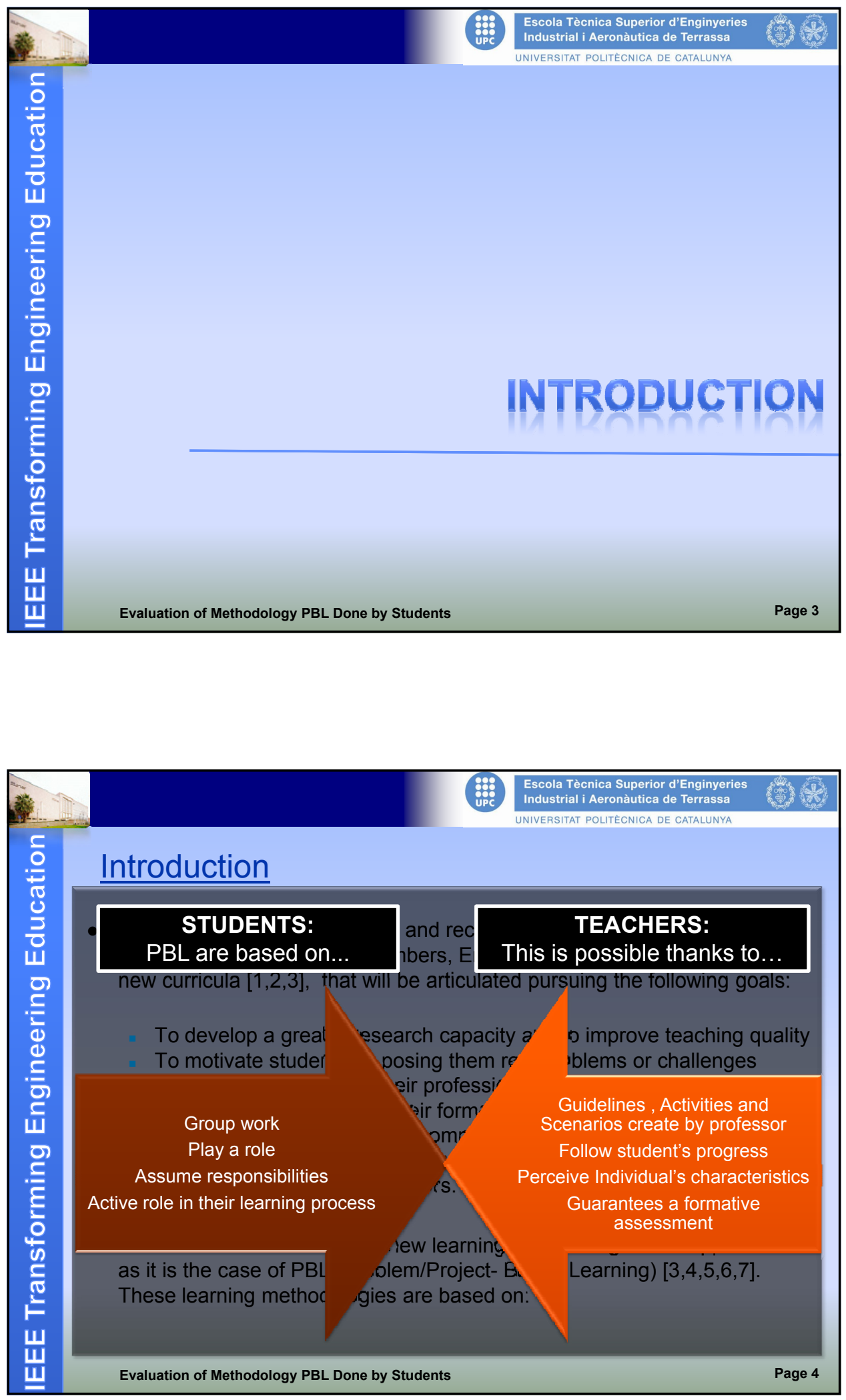


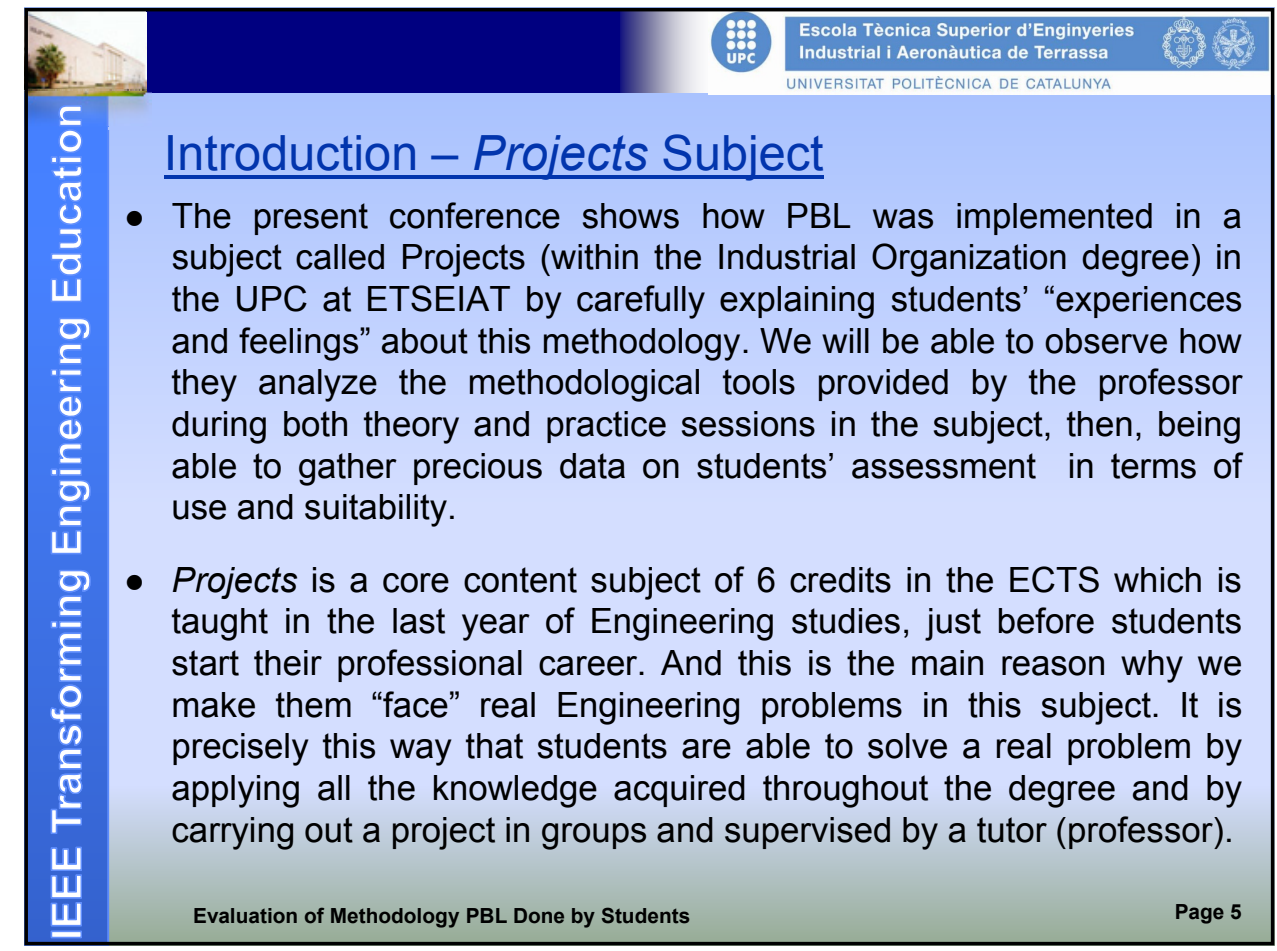

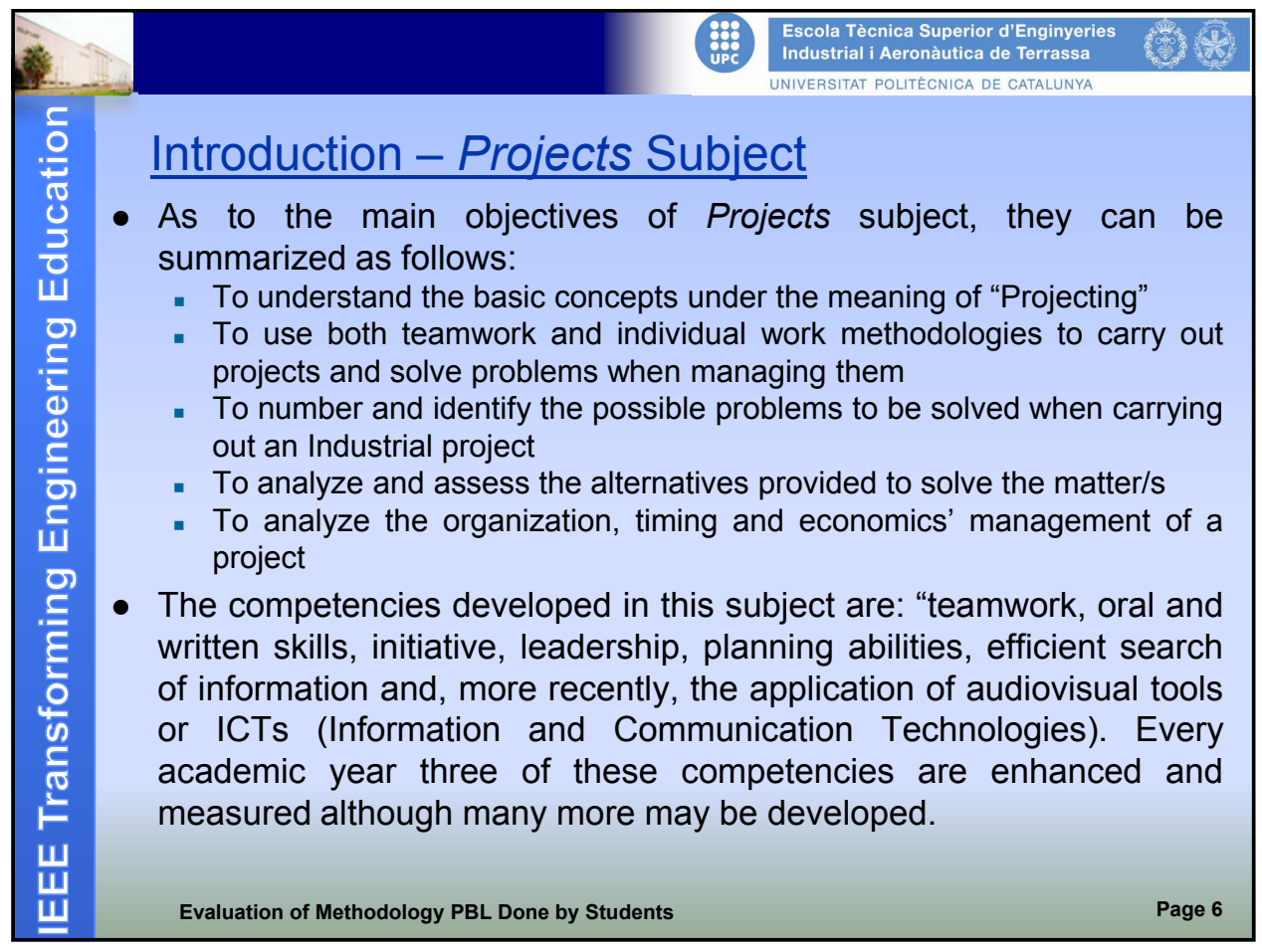



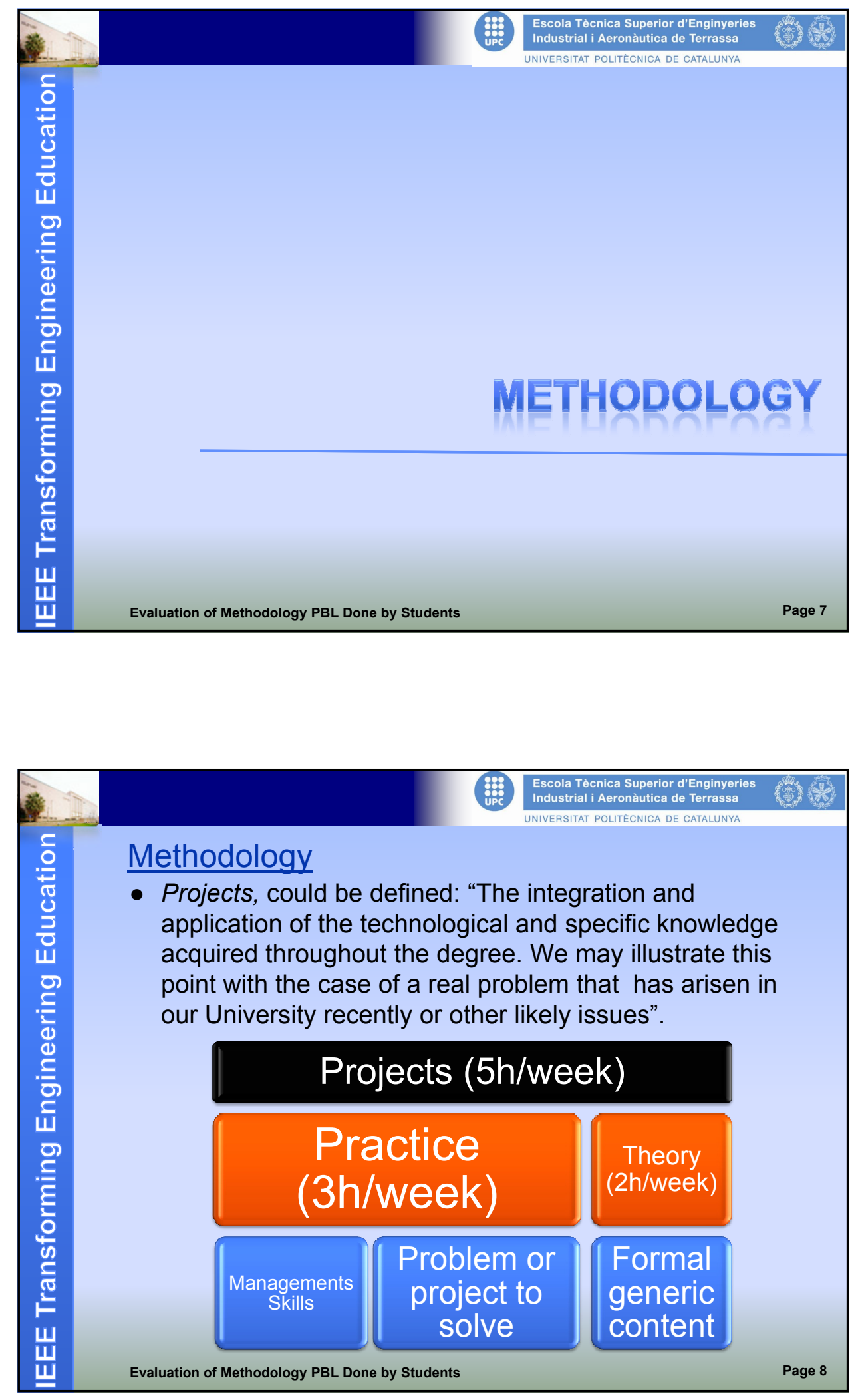

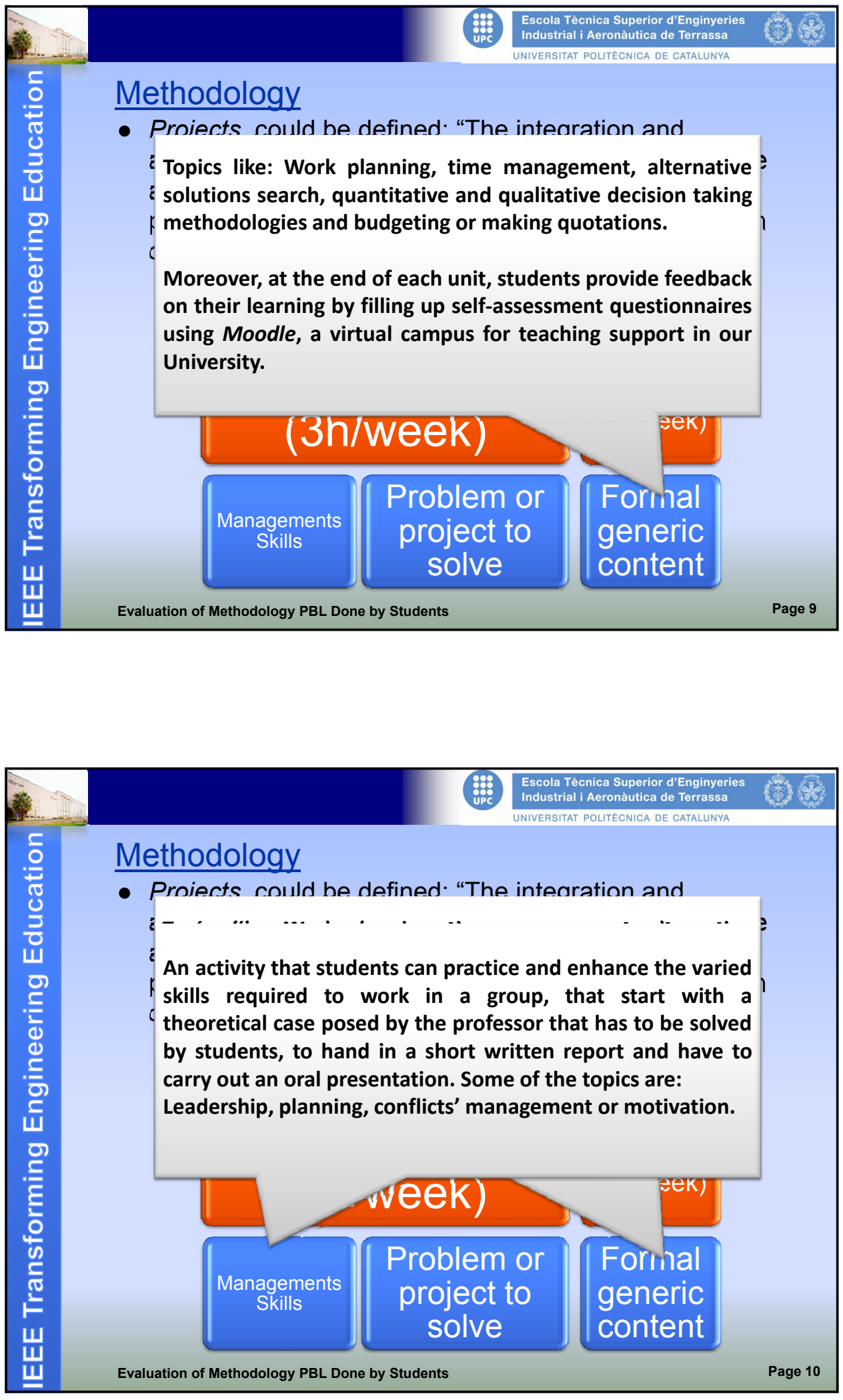

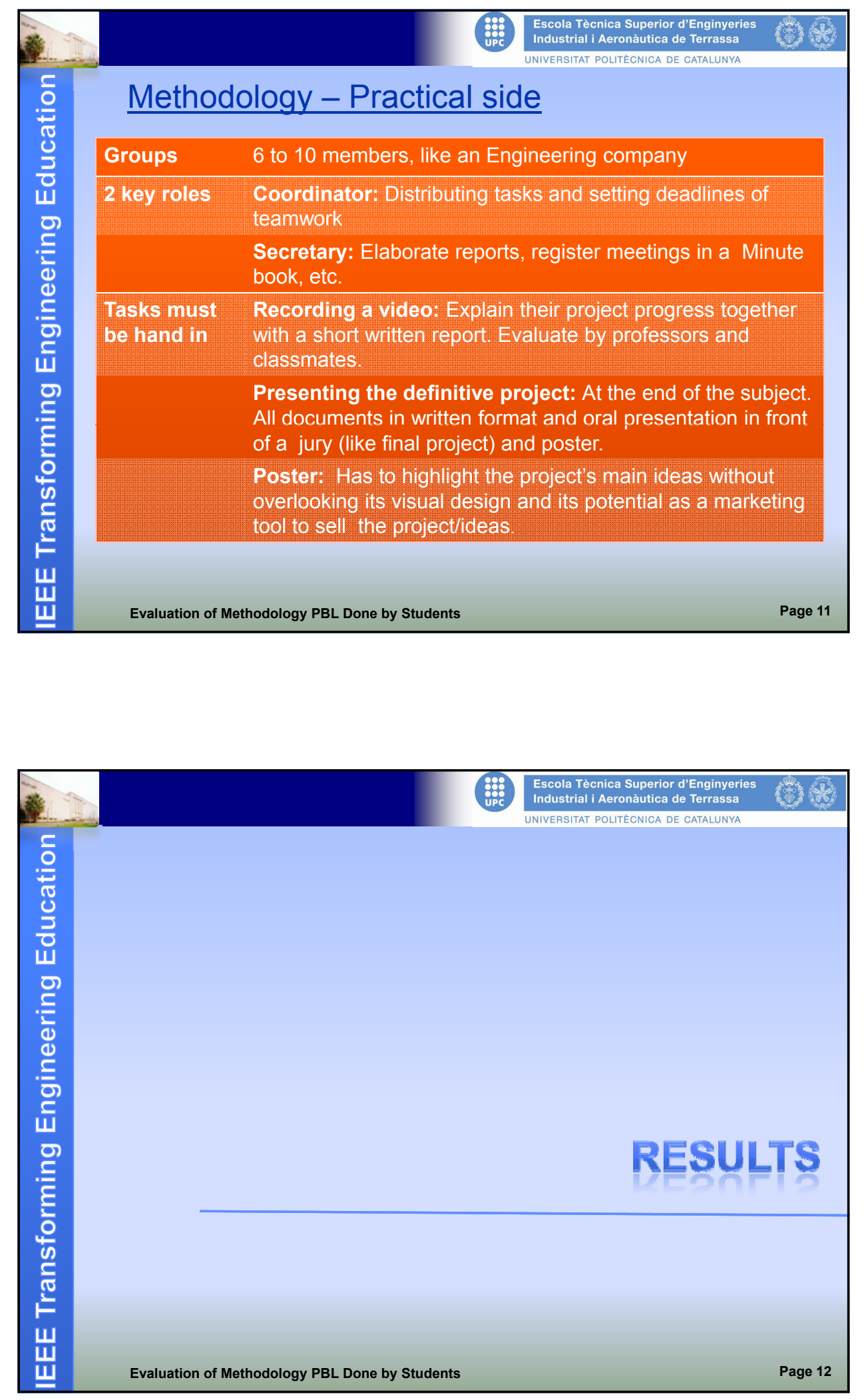

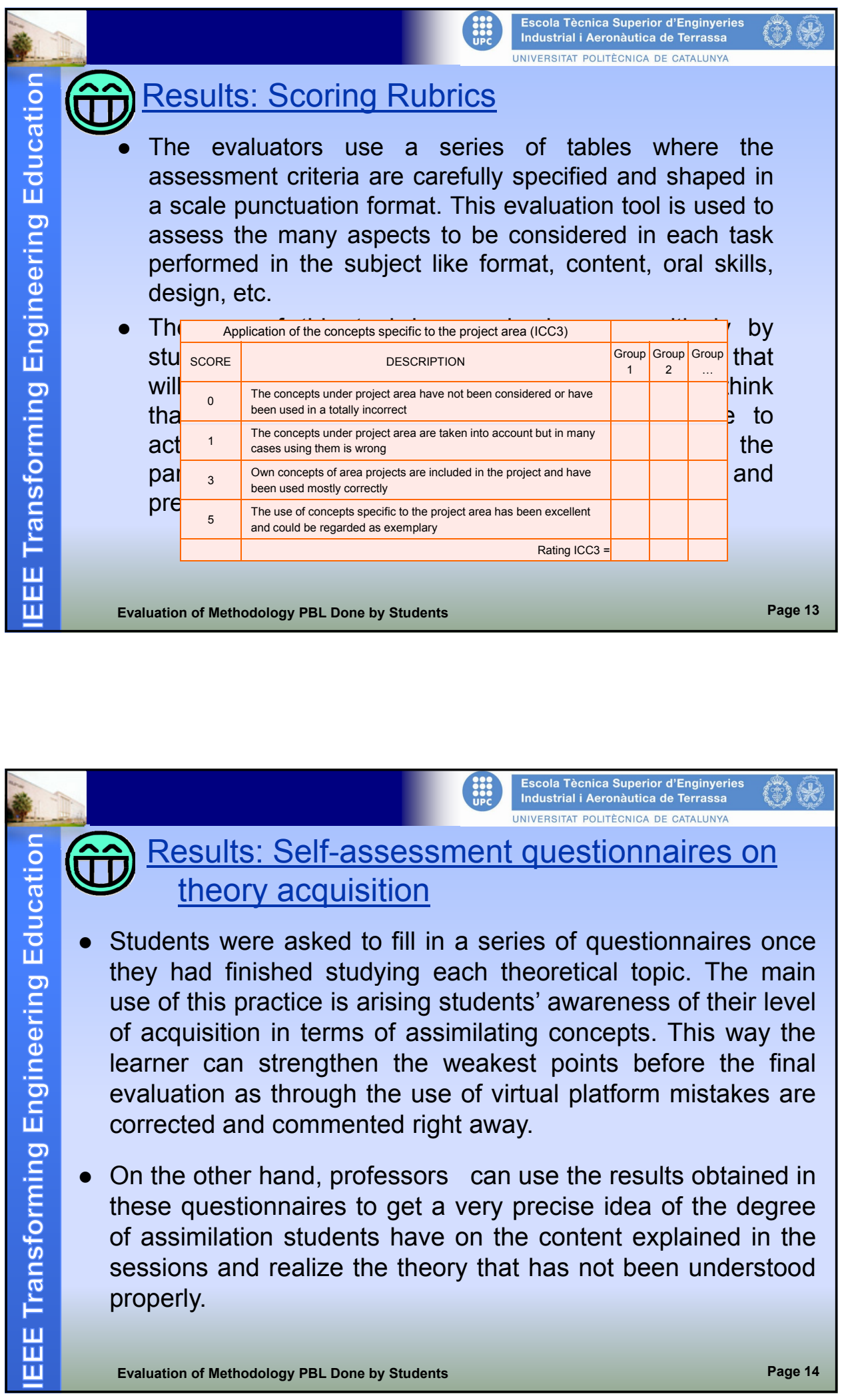

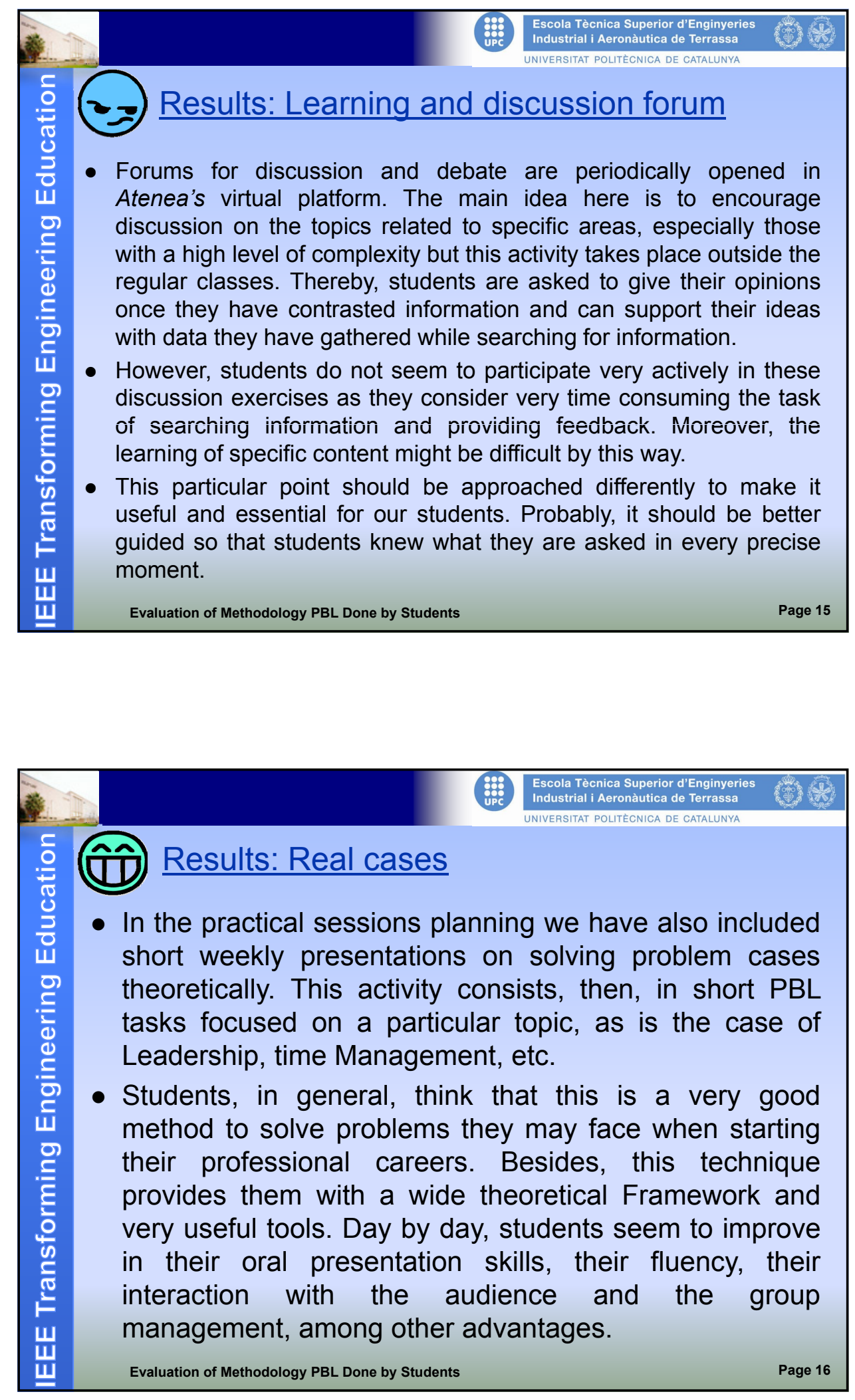

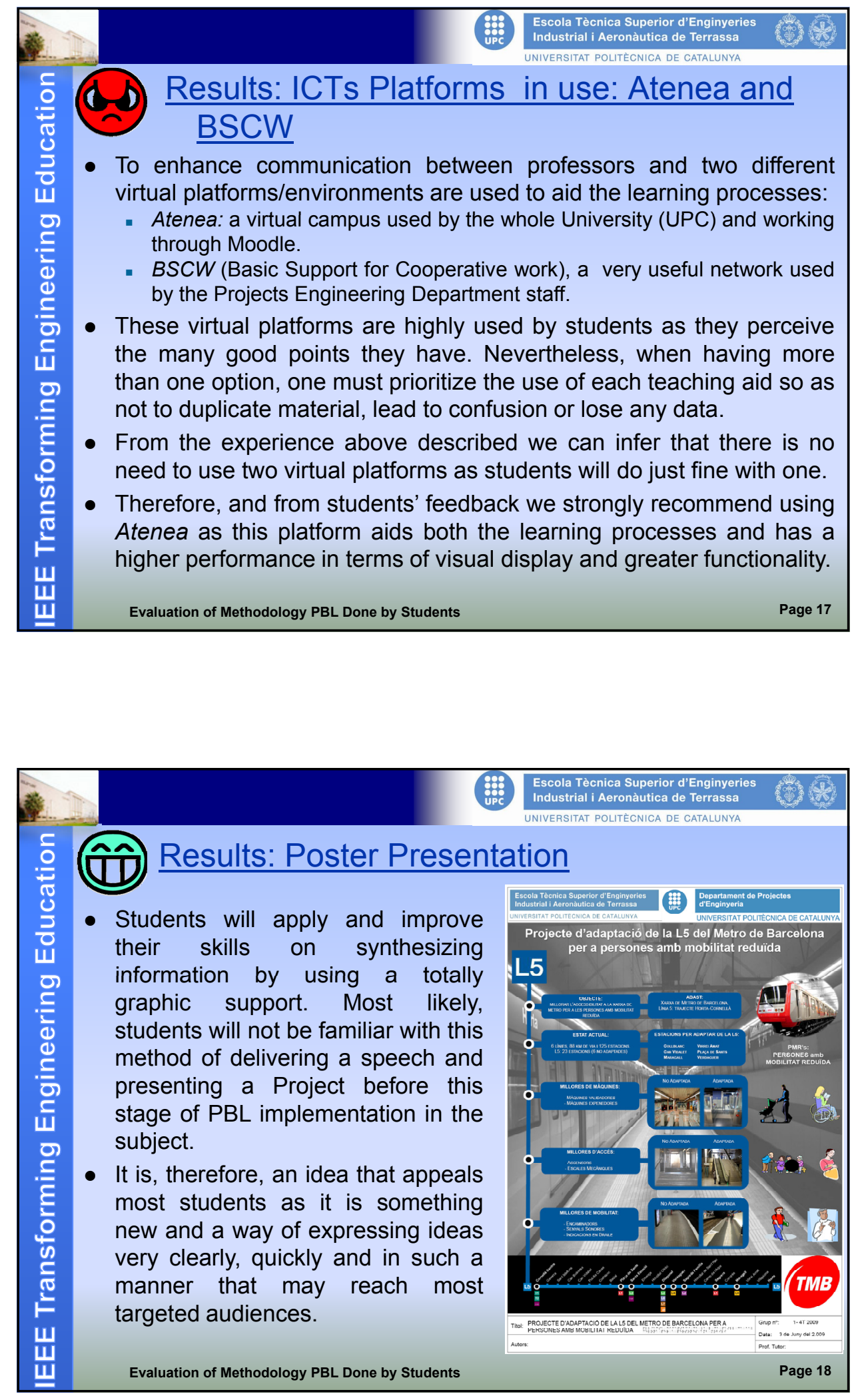

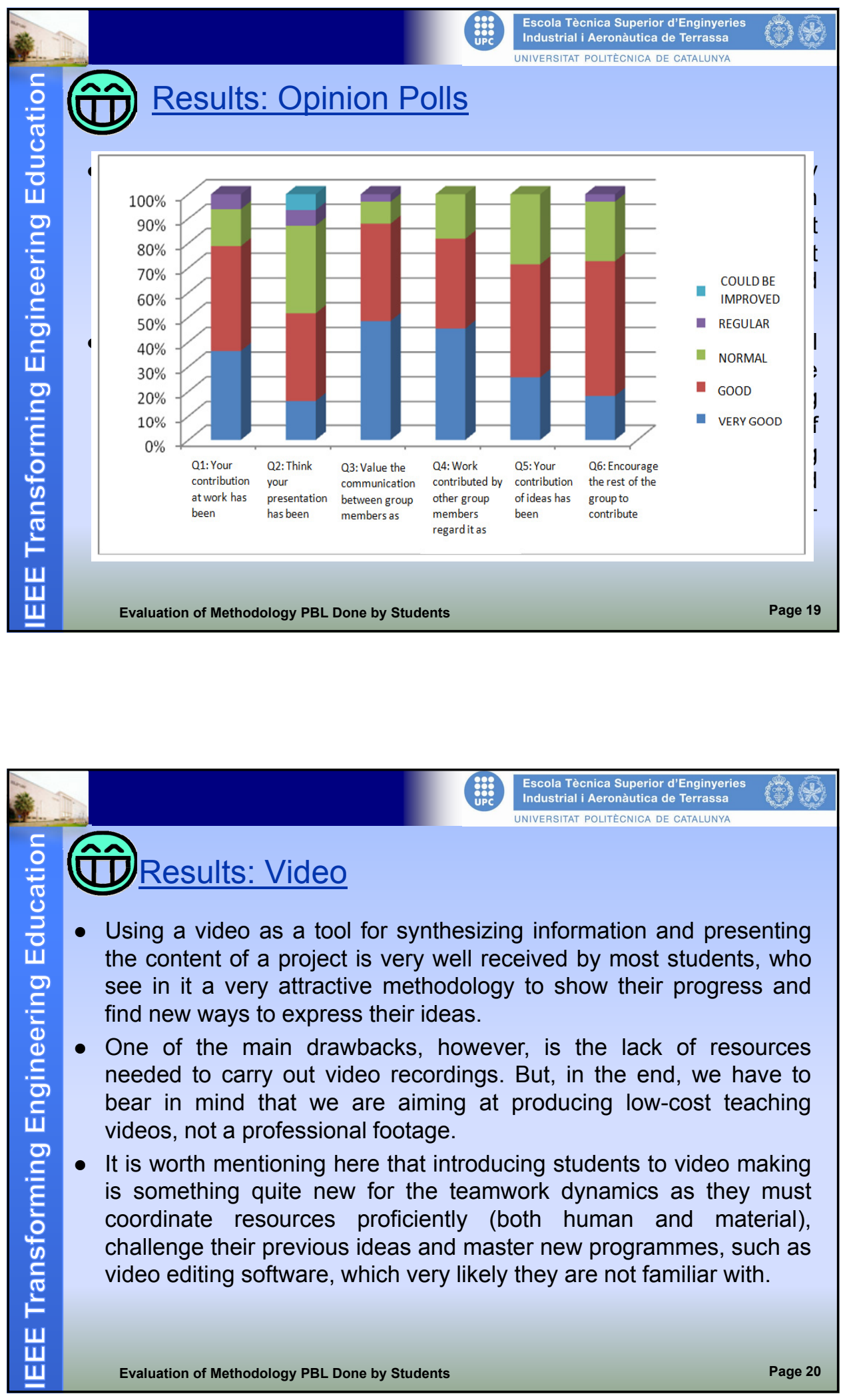

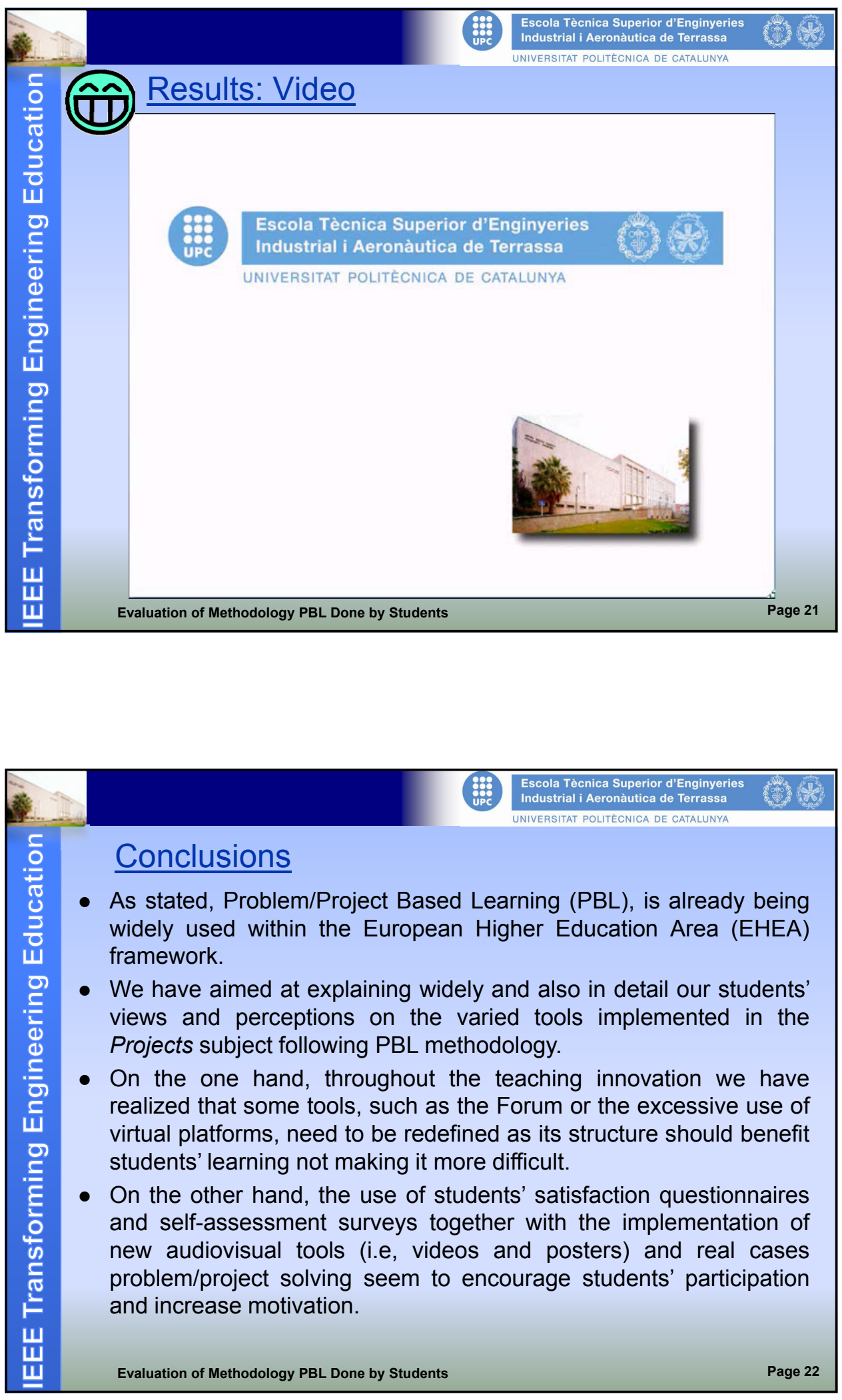


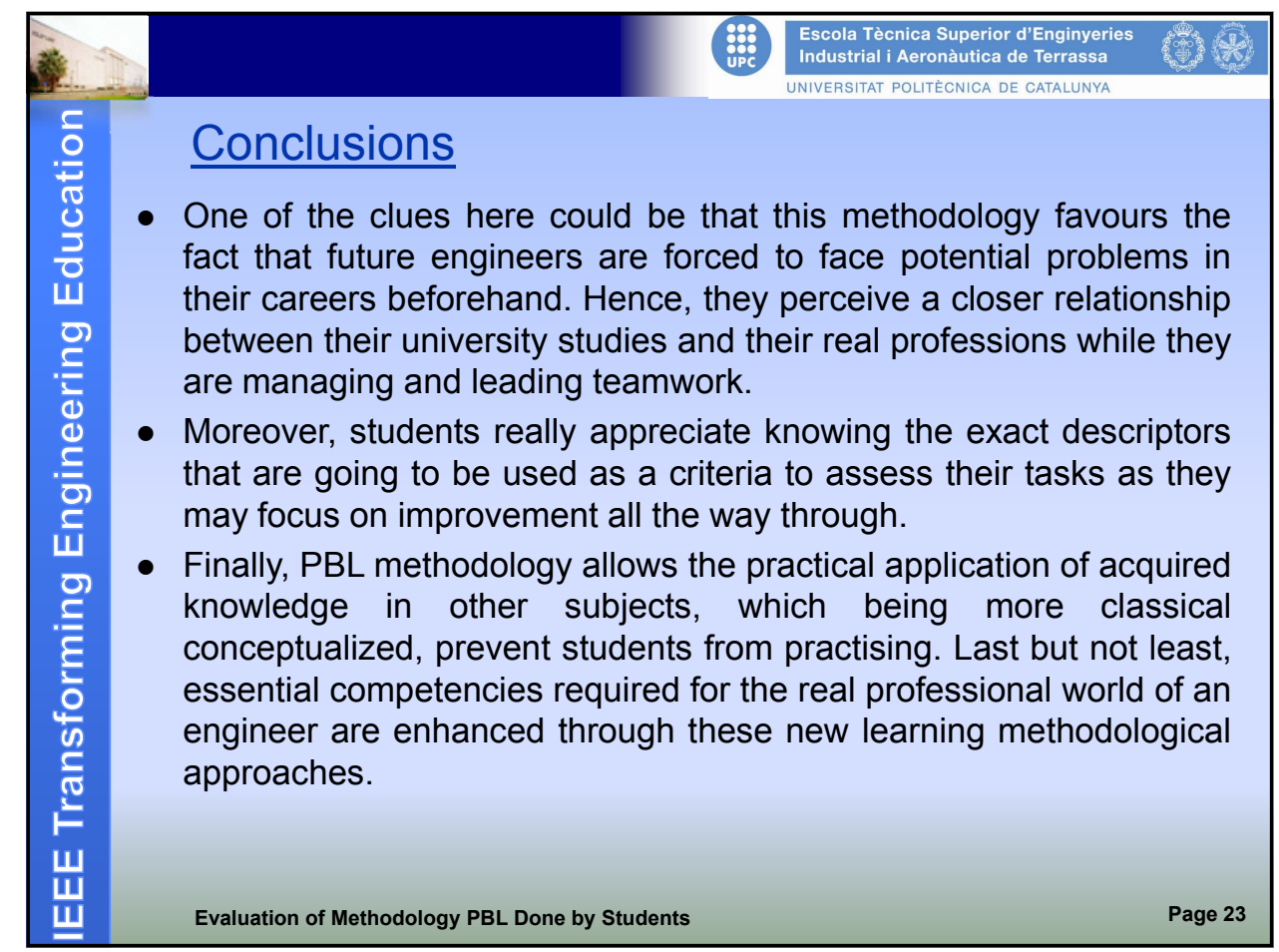

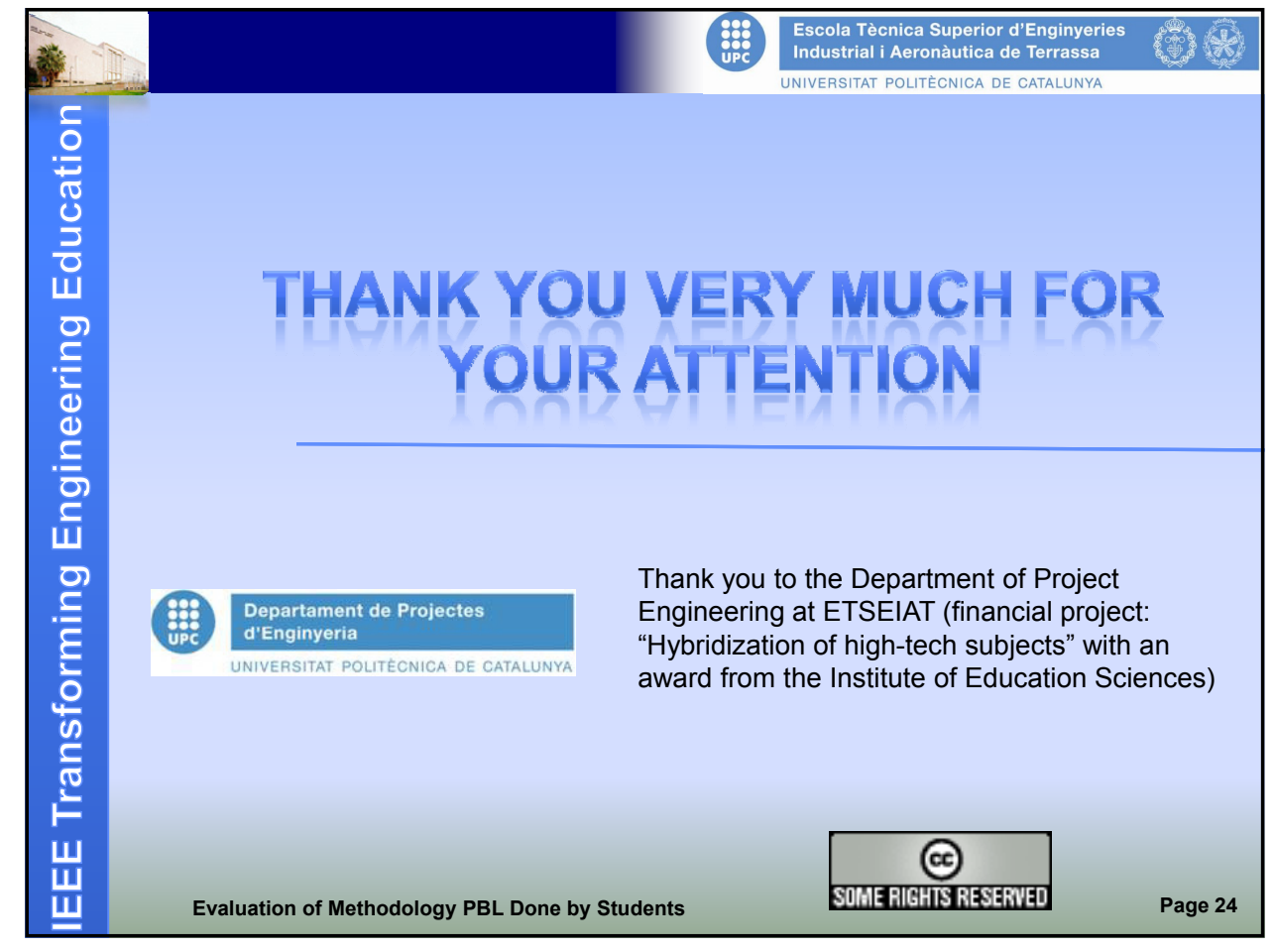




\begin{tabular}{|c|c|c|}
\hline & & 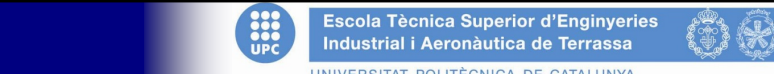 \\
\hline$\underline{\underline{c}}$ & \multicolumn{2}{|c|}{ Methodology - Evaluation Criteria for presentations } \\
\hline$\frac{\pi}{3}$ & $\begin{array}{c}\text { Evaluation } \\
\text { criteria(parameters) }\end{array}$ & Descriptors \\
\hline 䎡 & Clarity of ideas & The contents of the presentation are fully understood. \\
\hline 일 & Self-confidence & $\begin{array}{l}\text { The student seems nervous, shakes and/or seems to have } \\
\text { problems of delivery speed/tone/voice, etc. }\end{array}$ \\
\hline 든 & $\begin{array}{l}\text { Oral explanation not } \\
\text { reading }\end{array}$ & $\begin{array}{l}\text { The student adds information to the one provided in the } \\
\text { slides }\end{array}$ \\
\hline 들 & $\begin{array}{l}\text { Coherence and } \\
\text { cohesion of the slides } \\
\text { presented }\end{array}$ & $\begin{array}{l}\text { The student uses linkers and suitable connectors to present } \\
\text { and explain the different slides and defines the different } \\
\text { stages in the information process. }\end{array}$ \\
\hline 일 & $\begin{array}{l}\text { Length of the } \\
\text { presentation }\end{array}$ & $\begin{array}{l}\text { The time used in the oral presentation is suitable and follows } \\
\text { the initial timing. Proper speed of delivery. }\end{array}$ \\
\hline हᄐㅡㄴ & Position/Attitude & $\begin{array}{l}\text { The student shows enthusiasm /rhythm and signals the } \\
\text { required objects in the slides. }\end{array}$ \\
\hline$\frac{0}{6}$ & $\begin{array}{l}\text { Argumentative/reasonin } \\
\text { g skills }\end{array}$ & $\begin{array}{l}\text { The student is able to present arguments in a persuasive } \\
\text { way and support his/her reasoning. }\end{array}$ \\
\hline Ш & $\begin{array}{l}\text { Coherence in answering } \\
\text { questions }\end{array}$ & $\begin{array}{l}\text { The student is able to give a quick an appropriate answer to } \\
\text { the questions both the teacher and the classmates may } \\
\text { make. }\end{array}$ \\
\hline Ш & Evaluation of Methodology $F$ & 'BL Done by Students \\
\hline
\end{tabular}

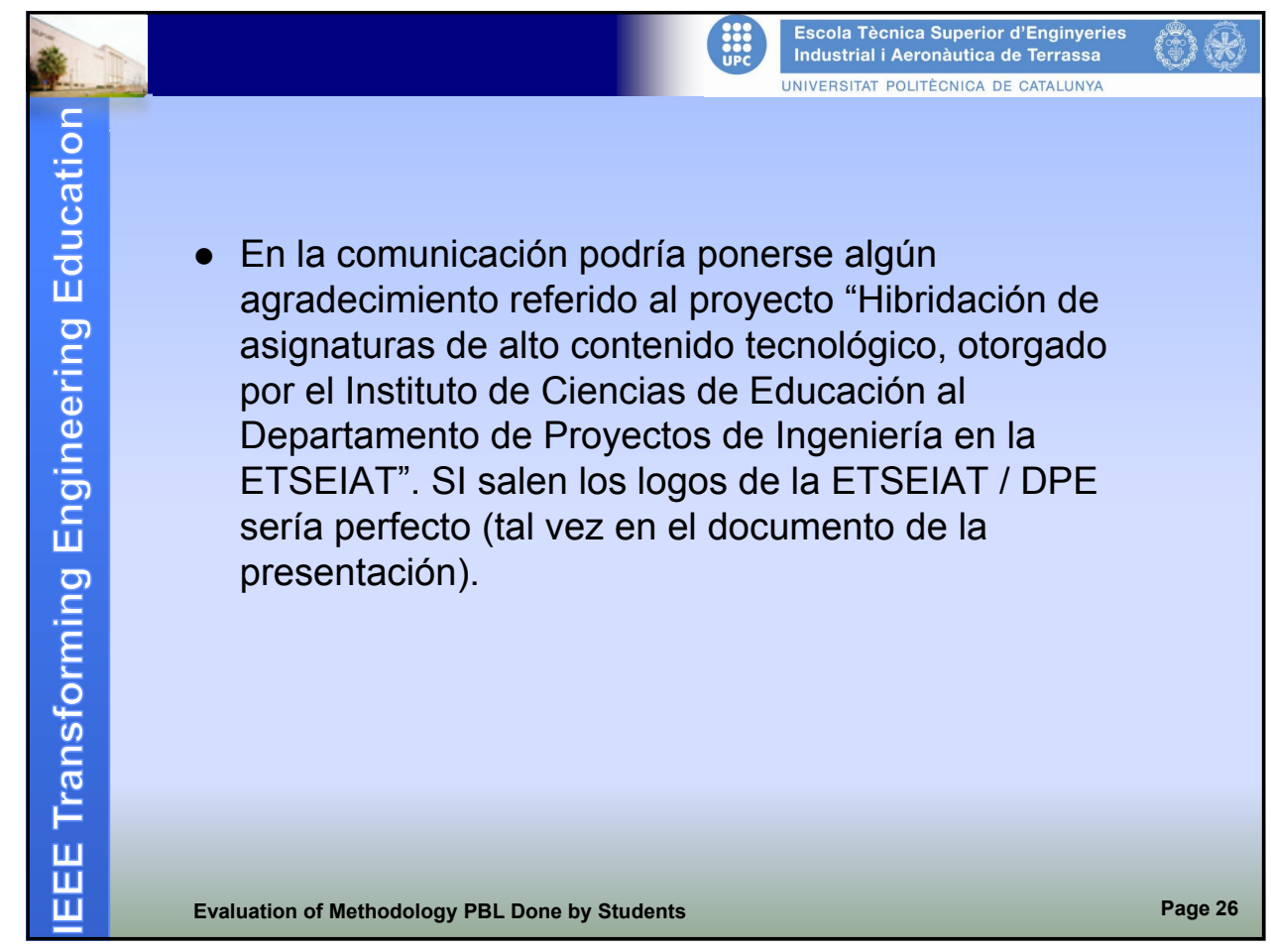

